\title{
Editorial
}

\section{THE METROPOLIS AS GATHERING PLACE: INTENDED AND UNINTENDED CONSEQUENCES...}

Those of us who have been intimately engaged in getting Latino Studies established or in gaining institutional recognition for our field, are familiar with unusual and sometimes irritating conversations with colleagues who, whether on paper or ideally, need not be won over to our side. At my previous institution where I spent over 10 years during the 1990s, for example, I was often forced to engage in several unsuccessful battles with the Latin American Studies program, for Latino and other students majoring in that field to be allowed to write their Senior Thesis about the transnational Latino experience. "Unfortunately," the Director and Associate Director would explain to me, "Latin American Studies stops at the 'Rio Grande'." Did they mean el Río Bravo? I had similar problems with the "American Civilization" faculty in my home department, where I was hired specifically to teach Latino Studies, but was not allowed to teach graduate-level courses. "You have to teach courses that people are interested in," they repeatedly said to me. I remember responding, "Then why did you hire a specialist in Latino Studies?" Needless to say, no real answers were forthcoming...

Undoubtedly, the insertion of the historical and contemporary experiences of US Latinos in the academy in this country has been and continues to be a source of constant tension, whether in our field's interaction with Latin American and American Studies, or in its relations to the various traditional disciplines, in both the social science and the humanities. Scholars in Latin American and American Studies alike, as my experience and that of many Latino Studies scholars attest, seem to perceive any attempt to introduce Latino Studies scholarship as muddying the apparently pristine waters of their "turf." Hence, they insist on zealously protecting their respective area's boundaries, with much of the same underlying and not-so-subtle fears as the border patrol guards against the intrusion of "the Other" today.

The traditional disciplines for their part continue to daintily introduce into their respective curricula, one or another "example" of US Latino research and writing (Sandra Cisneros' House on Mango Street, in English courses, Ramón Gutiérrez' When Jesus Came, the Corn Mothers Went Away: Marriage, Sexuality, and Power in New Mexico, 1500-1846 in US History courses, an article on "Puerto Rican immigrants" (sic!) in sociology courses, etc.), as if to say - as they did and still do in their departmental hiring practices - "one is enough.” Indeed, Universities hired (and continue

. Latino Studies 2006, 4, (1-4) (C) 2006 Palgrave Macmillan Ltd 1476-3435/06 \$30.00 www.palgrave-journals.com/lst 
to hire) one or, in fleeting moments of generosity, perhaps two Latino Studies scholars, to ensure "ethnic diversity" in their faculty and curricula. This situation often forces these scholars to choose between teaching only their specialization (whether Latina Literature, the sociology of Puerto Ricans, Chicano/a history) or performing the Herculean task of introducing, obviously in what can only be very general survey terms, aspects of the history, culture, literature, politics and socio-economic conditions of all the Latino nationalorigin groups. How else could they ensure that their students will leave their respective Universities with some idea of the multiple issues and perspectives they should research on their own, to understand the diverse histories, cultures, characteristics and experiences of the more than 40 million Latinos living in the United States today?

Undoubtedly, Latin American and Latino Studies have distinct origins, histories, and trajectories, and any attempt to lump them together does a disservice to these respective fields. As a Chilean scholar remarked at a midwestern Conference on Latin American and Latino Cultural Studies, a few years ago, "Ustedes tienen sus prioridades y problemas aquí, y nosotros tenemos los nuestros allá. Y no siempre son iguales."

And of course this is true. The relationship between the two fields forces us to go back to re-examine their respective histories, cultures, politics and contexts. It is not at all obvious that all Latinos are related to Latin Americans, nor is it self evident that Latin American scholars should have the same interest or concern about US Latinos as scholars based in the United States. It is indeed important to acknowledge that specific contexts, like elements of territoriality and turf are inevitable and, just as importantly, that neither field is a step child of the other. Nevertheless, it is also increasingly essential that our discussions about these fields and their relationship also keep in mind the ongoing reality of US hegemony in the hemisphere. For, the gathering of people of Latin American descent in this country - whether through conquest, as is the case of people of Mexican descent, through colonization, as is the ongoing reality of Puerto Rico, or through the neo-colonial relations with Latin American countries that are structured today by the forces of globalization and transnational migration points to an unmistakable and increasing movement of millions of people of Latin American descent, as well as of goods, capital and ideas to and from the United States. Hence, this contemporary flow and counter-flow has contributed to the possibilities for greater awareness, knowledge, research and scholarship about the realities of the countries on the Latin American continent - their regional and national commonalities as well as their differences. These impact on both Latino/a scholarship as well as on the research by Latin American scholars working on issues of immigration, remittances, political participation and social and cultural change in their respective home countries.

The US metropolis has become the gathering place for people of all the nations of the Americas. Moreover, once in the United States, US Latinos, 
whether Peruvians, Bolivians, Mexicans, Colombians, Puerto Ricans, Dominicans, or Salvadorans, are increasingly as hard pressed to stay up to date with the ongoing changes in their own countries, as they are with informing themselves about the realities of the continent as a whole. It is also increasingly difficult to ignore Latino realities within the USA. Thus, Latino Studies must continue to give constant attention to, and be reflective of the meanings of history, culture, politics, nationality, of people of Latin American descent. Equally important, however, is the reality that the discussion of the relationship between Latin American Studies and Latino Studies is not a given: rather, it is a constant and ongoing work in progress.

In this spirit, and for the reasons discussed above, we are pleased to present this special issue encompassing Latin American and Latino Studies. As Juan Poblete, editor of this special issue notes, the five articles in this issue are a product of the Hemispheric Dialogues project, a 6 year conversation funded by the Ford Foundation, among Latin American and Latino scholars and activists and housed at the University of California, Santa Cruz.

In addition to the articles Juan Poblete introduces here, we are also proud to include an extended number of short Vivencias essays, focusing on various aspects of canon formation - a key aspect of the foundations of any field. The section begins with a 1988 interview with Luis Leal, a pioneer in the definition and theorization of Chicano/a literary studies, introduced by Angie ChabramDernersesian. It then goes on to present essays by Tey Diana Rebolledo, Alan West-Durán, Ann Massman, Lisa Sánchez González and Bernadette Marie Calafell, discussing various aspects of the dilemma of canon formation - the personal and professional issues it raises, the choices we make or don't make in creating anthologies, the archiving of research materials and historical documents, and the gender and racial stereotypes that we are all seeking to break, through our individual and collective endeavors in the service of Latino Studies and, more broadly, of the Latino communities around the country. This issue also presents an extended book review section, which again points to the growing and diverse research and publications on US Latinos in the United States.

Last but not least, we once again publish the names of our reviewers, this time, for Volume 3 of our journal. It is a gesture which aims to show our appreciation for the work they, like those in previous years, continue to do, to make our journal a successful scholarly publication. In this context, we are proud to announce that Latino Studies was the runner-up for the Council of Editors of Learned Journals 2005 award for "Best New Journal" in the Council's "scholarly division."

As of this double issue, Latino Studies will be published as a quarterly. I am fully aware that this expansion, like the above-mentioned award, is the result of the hard work, commitment and ongoing support of all our reviewers, as much as it is of our authors, associate editors and managing editor, as well as our editorial board and our publisher, David Bull. Without the contributions and 
榇. latino studies - 4:1-2

4

enthusiasm of all who participate to ensure the ongoing publication of Latino Studies, this journal would not be what it is. Once again, muchísimas gracias a todos ustedes!

Suzanne Oboler University of Illinois at Chicago

Latino Studies (2006) 4, 1-4. doi:10.1057/palgrave.lst.8600196 